\title{
Risk Factors for Repeat Abdominal Surgery in Patients with Crohn's Disease
}

\author{
Young Jin Kim \\ Department of Surgery, Chonnam National University Hwasun Hospital, Chonnam National University Medical School, Hwasun, Korea
}

\section{See Article on Page 188-194}

Surgical intervention is a critical and mandatory treatment option to manage complicated Crohn's disease. Patients with Crohn's disease will finally need surgical treatment in 50 to $70 \%$ of the cases, and of those, 20 to $62 \%$ will require repeat surgery depending on the duration of the follow-up. There are several risk factors, such as age of onset, gender (male), genetic factor (NOD2, CARD15 gene), preoperative and/or postoperative medical therapy (infliximab, immunosuppression), smoking, behavior of lesions (ileocolic disease, long segment), operation type, and the urgency of operation, for reoperation after abdominal surgery for Crohn's disease [1]. However, these factors are still controversial according to different studies. Perforating Crohn's disease is more aggressive, requiring reoperation sooner $[2,3]$, and different clinical patterns of Crohn's disease have yet to be correlated with distinctive subclinical biologic markers [4].

Anastomotic recurrence was not associated with any clinical or histologic feature or with any combination of features of the resection margin [5]. Patients undergoing a strictureplasty alone are not more likely to require reoperation than those undergoing a resection. However, a simple diversion of the diseased bowel requires reoperation more frequently. Residual strictures and technical errors accounted for $20 \%$ of the reoperations within 2 years, ineffective medical therapy for $64 \%$, and severe disease despite medical therapy for $14 \%$ [6]. Thus, a need exists

Correspondence to: Young Jin Kim, M.D.

Department of Surgery, Chonnam National University Hwasun Hospital, Chonnam National University Medical School, 322 Seoyang-ro, Hwasun 519-763, Korea

Tel: +82-61-379-7642, Fax: +82-61-379-7661

E-mail:kimyjin@chonnam.ac.kr

(c) 2012 The Korean Society of Coloproctology

This is an open-access article distributed under the terms of the Creative Commons Attribution NonCommercial License (http://creativecommons.org/licenses/by-nc/3.0) which permits unrestricted noncommercial use, distribution, and reproduction in any medium, provided the original work is properly cited. for a comparative study of the effect on repeated abdominal operations of minimal invasive surgeries such as laparoscopic and robotic surgeries in patients with Crohn's disease.

\section{REFERENCES}

1. Baik SH, Kim WH. A Comprehensive review of inflammatory bowel disease focusing on surgical management. J Korean Soc Coloproctol 2012;28:121-31.

2. Aeberhard P, Berchtold W, Riedtmann HJ, Stadelmann G. Surgical recurrence of perforating and nonperforating Crohn's disease. A study of 101 surgically treated patients. Dis Colon Rectum 1996;39:80-7.

3. Sachar DB, Subramani K, Mauer K, Rivera-MacMurray S, Turtel P, Bodian CA, et al. Patterns of postoperative recurrence in fistulizing and stenotic Crohn's disease. A retrospective cohort study of 71 patients. J Clin Gastroenterol 1996;22:114-6.

4. Stebbing JF, Jewell DP, Kettlewell MG, Mortensen NJ. Recurrence and reoperation after strictureplasty for obstructive Crohn's disease: long-term results. Br J Surg 1995;82:1471-4 [corrected]. Erratum in: Br J Surg 1996;83:131.

5. Kotanagi H, Kramer K, Fazio VW, Petras RE. Do microscopic abnormalities at resection margins correlate with increased anastomotic recurrence in Crohn's disease? Retrospective analysis of 100 cases. Dis Colon Rectum 1991;34:909-16.

6. Binion DG, Theriot KR, Shidham S, Lundeen S, Hatoum O, Lim $\mathrm{HJ}$, et al. Clinical factors contributing to rapid reoperation for Crohn's disease patients undergoing resection and/or strictureplasty. J Gastrointest Surg 2007;11:1692-8. 